\title{
Green supply chain management practices and destination image: Evidence from Vietnam
} tourism industry

\author{
Anh Duc Doa ${ }^{a}$ Quang Vinh Nguyen ${ }^{b}$, Duy Uan Nguyenc, Quoc Hoi Le ${ }^{d^{*}}$ and Dinh Uyen Trinh
}

${ }^{a} V N U$ University of Economics and Business, Vietnam National University, Vietnam

${ }^{b}$ Hanoi University of Business and Technology, Vietnam

${ }^{c}$ Asia E University, Malaysia

${ }^{d}$ National Economics University, Vietnam

${ }^{e}$ Trung Vuong University, Vietnam

\section{H R O N I C L E}

Article history:

Received October 20, 2019

Received in revised format

November 14, 2019

Accepted November 142019

Available online

November 142019

Keywords:

Green supply chain

management

Tourism industry

Destination image

PLS- SEM

Vietnam

\section{Introduction}

Since there are many problems in exploring the tourism resource and the traditional supply chain cannot meet the international quality standard, and some related technologies are not available in Vietnam, there is a need for implementing Green Supply Chain Management Practice (GSCM). Sustainability issues have been receiving an increasing attention from both practitioners and researchers in the hospitality industry in recent years (Berezan et al., 2013). One of the reasons for this increase is that an increasing number of travelers pay close attention to sustainability actions of companies (U.S. Travel Association, 2009) and hold positive attitudes toward companies implementing sustainable actions (Xu \& Gursoy, 2015). In considering why tourist companies should use green supply chains, a series of studies argue that compliance with regulations is a major driver that contributes to the implementation of green supply chains (An et al., 2008; Dam, 2017). Ho et al. (2009) suggest that some of these

* Corresponding author

E-mail address: hoilq@neu.edu.vn (Q.H. Le)

(C) 2020 by the authors; licensee Growing Science. doi: $10.5267 /$ j.uscm. 2019.11 .003

\begin{abstract}
A B S T R A C T
Vietnam is one of the most popular tourist destinations in the Asia-Pacific region and its tourism industry has been growing unprecedentedly over the past few years. However, the paper aims to analyze Green Supply Chain Management Practice (GSCM) and its effect on the destination image of Vietnam as the way to improve the completeness. The paper seeks to examine internal environment management (IEM) practices; external environment (EE) and environmental regulation (ER), as possible drivers to GSCM practices and its destination image. The empirical analysis used data from 269 questionnaires which were valid for analysis, through applying the PLS- SEM method. The result of path analysis indicates that the path between internal environmental management and GSCM practice in the VTI was highly significant; internal environmental management (IEM) had a significant impact on the external environment and also had a significant impact on destination image in VTI. The external environment has also maintained a significant impact on the GSCM practices of the VTI and on destination image in VTI. There is also a positive relationship between GSCM and destination image in VTI. As a result, it can be concluded that all hypotheses are supported. This paper concludes with a discussion of the implications of the findings from the study for tourism managers.
\end{abstract}

(C) 2020 by the authors; license Growing Science, Canada. 
organizations are enhancing their competitiveness through improvements in their environmental performance to comply with mounting environmental regulations, to address the environmental concerns of their customers, and to mitigate the environmental impact of their production and service activities. Competition in the global market is becoming increasingly fierce pressure to the tourism industry, forcing them to cut costs, improve product quality, together with the increased level of customer service (Tseng, 2010). Also, the study suggests that sustainability practices have become significant determinants of customer loyalty and improving the destination image.

Vietnam has a long coastline, beautiful natural scenery and a culture of rich identity. These are great advantages for tourism to become the key economic sector of the country. 2017 is considered the impressive development of tourism in Vietnam with the highest number of international visitors with nearly $30 \%$ increase compared with 2016. During the year of 2018, the number of tourists and total revenue from tourists continued to grow strongly at 15.6 million international visitors (2.6 million more visitors compared with 2017), and total revenue from tourists reached more than VND 620,000 billion. The tourism industry creates a great potential and it has achieved initial results and there is still bigger potentials and expectations for Vietnam society. Nguyen (2010) concludes that, many Vietnam tourism companies find it hard to evaluate their own competitiveness, resulting in their inability to seek effective solutions to enhance it. In order to help receive more foreign visitors to Vietnam, there is a need to do some scientific works on competitiveness evaluation of Vietnam Tourism Industry (VTI) under GSCM approach. Managing the supply chain is the fusion of travel and business process mainly from the initial suppliers (goods, travel services) to final users (tourists) to provide the product, services and information to create added value for business travelers and tourists. The creation and supply chain management efficient tourism will help optimize the benefits for stakeholders (suppliers, tourists and locals). At the same time, it contributes to the development of Vietnam tourism and building strong and sustainable future (Vinh et al., 2015). The field of supply chain management has more recently directed its attention to the role of the supply chain in both (a) impacts to the natural environment and (b) the generation of environmental performance change. Since most of the goods and services included in a holiday package are provided by a supply chain of subcontracted companies, organizations and agents, hotel managers are not always in direct control of the environmental and social impacts of those products (Zhang et al., 2009). Consumers increasingly expect the companies that they purchase goods to ensure not only the quality and value-for-money, but also the safeguard environmental and social sustainability (Vinh et al., 2015). Besides, many studies have indicated that both the environmental and economic dimensions have positive influences on customer satisfaction and destination image. However previous studies still provide limited findings about the positive impact of GSCM in tourism on destination image (Jang et al., 2015; Xu \& Gursoy, 2015; Berezan et al., 2013 Lee et al., 2010). Thus, this study is timely and necessary to better aid VTI in the GSCM principles. The main objectives of this study are to analyze the relationship between green supply chain management practice and destination image.

\section{Literature Review}

In recent years, the phrase "green supply chain" has been mentioned more frequently. Concerning it, many terms have been used as "sustainable supply chain", "sustainable green supply chain", "environmental supply chain", "ecological supply chain". Beamon (1999) emphasized the importance of cooperating with a company and defining green supply chain management by using the supply chain between a central company and a cooperative company, to support organizations, ecological management know-how in the central companies and the development of clean production techniques. Sarkis (2012) also defines green supply chain management as a combination of a revamped environmental and logistics company, which emphasizes the importance of reverse logistic. So green supply chain management is the process of adding "green" elements to existing supply chains and creating a recalled supply chain as a rebuilding system in a bright way. This includes not only effective pursuit, but also innovation in the supply chain related to costs, profits, and the environment. To ensure 
environmental excellence, top management must be totally committed. Carter et al. (1998) concluded that support from middle managers is also essential to the successful implementation of GSCM practices. Bowen et al. (2001) used middle-level managers to find positive relationships between middle-level managers' perceptions of corporate environmental proactivity and environmental management. Communication between business managers and environmental professionals is also important in a successful business and environmental relationship. Chien and Shih (2007) asserted that it is important to evaluate the performance of GSCM inside the organization. Environmental performance is commonly measured through operative performance indicators and management performance indicators (Cagno et al., 2011). Moreover, for hotels that pay special attention to the performance of GSCM, internal environmental management (IEM) is more influential in stressing GSCM. Lin (2011, p.2) stated that "due to customer demands for green products which are manufactured using environmentally friendly raw materials and green production processes, firms have to integrate its environmental goals with long-term strategic management". Consumer pressure certainly stimulates the environmental performance of other industries, notably the high-street hotel industry (Phan, 2019). While the growth of boutique eco-hotels suggests a growing clientele for such services, all organizations in the hotel industry must ensure the sustainability of all the components of their products (Sigala, 2008). Whereas first-time guests usually choose their hotels based on location, amenities and services, returning customers may base their decisions on the level of environmental commitment.

Literature shows that all suppliers need to cooperate and translate sustainability policies and metrics into actionable, sustainable goals, the current and future performance levels of which can be traced and monitored. Vachon and Klassen (2008), Nguyen (2010) and Sundarakani et al. (2010) argued that technology and innovation, transparency and the enhancement of supplier relationships are important factors in the management of green supply chains, though there are many factors that should be considered in green supply chain management. According to the theories mentioned above, the relationship with suppliers is the most important factor for GSCM. Further, Ho et al. (2009) also indicated that building a good relationship with suppliers can benefit both parties when they work together to improve product design and product efficiency, which can lead to more waste reduction. Zhu et al. (2008) conclude that the success of eco-design requires internal, cross-functional cooperation within the company and external cooperation with other partners throughout the supply chain. According to Vachon and Klassen (2006), it is better for corporations to establish long-term relationships with suppliers, which includes establishing requirements for product quality, following environmental regulations at the manufacturing level, having green packaging and distribution strategies and delivering high-quality products to customers ( $\mathrm{Xu} \&$ Gursoy, 2015). The discussion above leads to the second hypothesis. In considering why firms use green supply chains, a series of studies argue that compliance with regulations is a major driver that contributes to the implementation of green supply chains (An et al., 2008). Zhu and Sarkis (2006) divide the regulatory environment into three levels: regional environmental regulations, central government environmental regulations, and international environmental regulation agreements. To balance rapid economic growth, rapidly improving hotel service quality and environmental impact, the government of Vietnam must introduce certain policies and regulations to facilitate the development of sustainability (Lai \& Vinh, 2013). According to Cater and Rogers (2008), sustainability involves three components: environmental, social and economic performance. Although governments aim to perform well in all areas, they pay the most attention to regulating environmental issues. To slow environmental degradation, sustainability is advocated (Jang et al., 2015). In considering this issue, developed countries took several measures, such as publishing certain laws and standards to control environmental impacts (Xu \& Gursoy, 2015). However, in developing countries such as Vietnam, sustainability is still a new topic. Policies and approaches related to sustainability are incomplete, and the development of sustainability is at an early stage (Lai \& Vinh, 2012). As concluded by Ling (2015) "The concept of sustainable development is the inevitable choice of supply chains management. For tourism industry, all the enterprises in the supply chains should be responsible for travel resources protection and long-term development 
coordination". Based on the perspective of sustainable development supply chain, a number of optimization strategies are suggested for green consumption in this paper, which includes tourism resources development and design, daily operation management, product marketing and culture promotion. Besides, these practices can further examine the research in the future and improve

$\mathrm{H}_{1}$ : Internal environmental management (IEM) has a significant impact on GSCM practice in the VTI. $\mathrm{H}_{2}$ : Internal environmental management (IEM) has a significant impact on the external environment. $\mathrm{H}_{3}$ : Internal environmental management (IEM) has a significant impact on destination image in VTI. $\mathrm{H}_{4}$ : The external environment has a significant impact on the GSCM practices of the VTI. $\mathrm{H}_{5}$ : The external environment has a significant impact on destination image in VTI. $\mathrm{H}_{6}$ : There is positive relationship between GSCM and destination image in VTI.

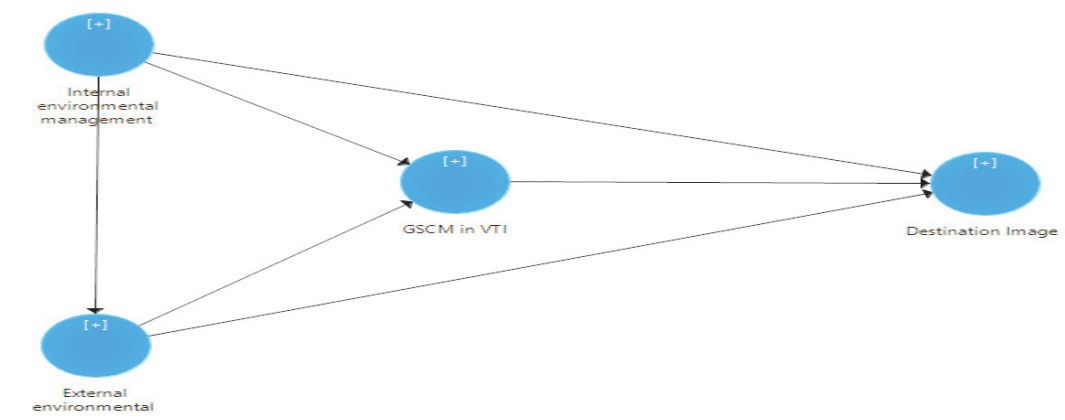

\section{Methodology}

Fig. 1. Research model

Based on literature discussed above, the technique for creation of attributes for this thesis is based on literature review, pilot sample, researcher's judgment and experts. The structured questionnaire is employed. The communication approaches selected are both "survey via personal interview" and "selfadministered survey". For this study, we have chosen the form of interview as a method to collect data. Our goal is to collect 400 samples of survey questions from different units of tourist companies and hotels in the northern of Vietnam. This study uses a survey questionnaire to elicit perceptions/opinions about GSCM from managers in the VTI. The survey instrument includes questions seeking demographic information. The questionnaires were mailed to managers working in tourism industry in northern of Vietnam. The SPSS 20.0 and PLS-SEM 3.0 software were applied to analyze and verify the gathered data and the hypothesis developed. This study reviews scholars' literature based on the research and practice of GSCM, the appropriate measurement scales of Zhu et al. (2008), Chen et al. (2011), and Diabat and Govindan (2011) and information gathered from expert interviews. The destination image is developed by author with three items include "Tourist have a positive opinion about this green tourist destination. This tourist destination has a unique image and becoming popular related to green product and This tourist destination respects the natural environment". In the literatures, destination image research is mostly conducted with current or potential tourists however, according to Dunn (2005, p. 80), conducted survey with the supplier and it is an excellent method of gaining access to information and collecting a diversity of opinions and experiences. The following suggestions and recommendations outlined by Dunn (2005, pp. 79-105) were taken into consideration and provided a valuable basis for the conduction of the survey. The questionnaire was distributed firstly to 30 managers to check how they understand the questions. Afterward, questionnaire was revised to become the final version and ready for collecting data. There are 316 questionnaires distributed to staffs and managers who were working in hotels and travel companies. 280 questionnaires were sent back to authors in which 269 ones were valid for analysis which represents 64\%. Table 1 shows the respondent information. 
Table 1

Respondent information

\begin{tabular}{|c|c|c|c|c|c|c|c|}
\hline & & Frequency & Percent & & & Frequency & Percent \\
\hline \multirow[t]{2}{*}{ Gender } & Male & 174 & 64.7 & \multirow{6}{*}{ Market } & USA & 51 & 19.0 \\
\hline & Female & 95 & 35.3 & & China & 55 & 20.4 \\
\hline \multirow[t]{4}{*}{ Experience } & $<5$ year & 17 & 6.3 & & EU & 37 & 13.8 \\
\hline & $5-10$ year & 50 & 18.6 & & ASEAN & 31 & 11.5 \\
\hline & 11-15 year & 118 & 43.9 & & Asia & 39 & 14.5 \\
\hline & $>15$ year & 84 & 31.2 & & Others & 56 & 20.8 \\
\hline \multirow[t]{4}{*}{$\overline{\text { Age }}$} & $<25$-year-old & 42 & 15.6 & \multirow{3}{*}{ Business type } & Hotels & 134 & 49.8 \\
\hline & 26 - 35-year-old & 114 & 42.4 & & Travel & 66 & 24.5 \\
\hline & 36 - 45-year-old & 85 & 31.6 & & Destination & 69 & 25.7 \\
\hline & $>45$-year-old & 28 & 10.4 & Total & 269 & 100.0 & Total \\
\hline
\end{tabular}

\section{Data analysis}

\subsection{Reliability and Validity of Model}

Construct validity, determined through the presence of convergent and discriminant validity, demonstrates how well the measurement items relate to the constructs. To demonstrate convergent validity, we have used three tests: item reliability, composite reliability, and average variance extracted. Cronbach's alphas also provide evidence of composite reliability and values above 0.6 demonstrate that they are adequate. All the composite reliabilities for our constructs were above 0.7 and all the Cronbach's alphas were above 0.6 (see Table 2). Finally, the average variance extracted (AVE) represented the amount of variance a construct captures via its items relative to the amount of variation due to measurement error. We have found that each construct's variance extracted was above the recommended value of 0.5 .

Table 2

Construct Reliability and Validity

\begin{tabular}{lcccc}
\hline & $\begin{array}{c}\text { Cronbach's } \\
\text { Alpha }\end{array}$ & rho A & $\begin{array}{c}\text { Composite } \\
\text { Reliability }\end{array}$ & $\begin{array}{c}\text { Average Variance Extracted } \\
\text { (AVE) }\end{array}$ \\
\hline Destination Image & 0.805 & 0.844 & 0.816 & 0.604 \\
External environmental & 0.881 & 0.886 & 0.882 & 0.600 \\
GSCM in VTI & 0.884 & 0.891 & 0.885 & 0.721 \\
Internal environmental management & 0.898 & 0.901 & 0.898 & 0.638 \\
\hline
\end{tabular}

Thus, we have concluded that all our constructs had satisfactory convergent validity. We have used two tests for discriminant validity: comparison of item loadings with item cross loadings and comparison of the variance extracted from the construct with shared variance. Each item should load more highly on its intended construct than on other constructs. We have found that all our items satisfied this condition (see Table 2).

Table 3

Convergent validity analysis

\begin{tabular}{lcccc}
\hline & $\begin{array}{c}\text { Destination } \\
\text { Image }\end{array}$ & $\begin{array}{c}\text { External } \\
\text { environmental }\end{array}$ & $\begin{array}{c}\text { GSCM in } \\
\text { VTI }\end{array}$ & $\begin{array}{c}\text { Internal environmental } \\
\text { management }\end{array}$ \\
\hline Destination Image & $\mathbf{0 . 7 7 7}$ & & & \\
External environmental & 0.687 & $\mathbf{0 . 7 7 5}$ & & $\mathbf{0 . 8 4 9}$ \\
GSCM in VTI & 0.612 & 0.691 & 0.673 & $\mathbf{0 . 7 9 9}$ \\
Internal environmental management & 0.688 & 0.749 & \\
\hline
\end{tabular}

\subsection{PLS structural model results}

We next examined the overall explanatory power of the structural model, the amount of variance explained by the independent variables, and the magnitude and strength of its paths, where each of our 
hypotheses corresponds to a specific structural model path. We used Adjusted R-Squared to measure the model's explanatory power, interpreted in the same way as for regression analysis. The explained variation should exceed $10 \%$ to qualify for suitable explanatory power. The analysis revealed that the structural model explained about $54.7 \%$ of the variation of destination image, $55.9 \%$ of the variation in External environmental and 53\% of the variation of GSCM in VTI suggesting that the structural model provided adequate explanatory.

\section{Table 4}

Adjusted R-Square

\begin{tabular}{lcc}
\hline & R Square & R Square Adjusted \\
\hline Destination Image & 0.552 & 0.547 \\
External environmental & 0.561 & 0.559 \\
GSCM in VTI & 0.533 & 0.530 \\
\hline
\end{tabular}

From the path analysis, the result indicates that the path between Internal environmental management and GSCM practice in the VTI is highly significant $(\mathrm{t}=4.269, \mathrm{P}<0.05)$, fully supporting hypothesis $\mathrm{H} 1$ "Internal environmental management (IEM) has a significant impact on GSCM practice in the VTI". $\mathrm{H} 2$ "Internal environmental management (IEM) has a significant impact on the external environment" is strongly supported $(\mathrm{t}=12.665, \mathrm{P}<0.05), \mathrm{H} 3$ stated that: Internal environmental management (IEM) has a significant impact on destination image in VTI, is supported $(\mathrm{t}=4.047, \mathrm{P}<0.05)$. H4 is supported when stated that: The external environment has a significant impact on the GSCM practices of the VTI $(\mathrm{t}=4.429, \mathrm{P}<0.05), \mathrm{H} 5$ : The external environment has a significant impact on destination image in VTI is also supported $(\mathrm{t}=3.646)$; and finally, the last hypothesis H6: There is positive relationship between GSCM and destination image in VTI is also supported $(\mathrm{t}=2.575)$. As the result it can be concluded that all hypotheses are supported as shown in Fig. 2

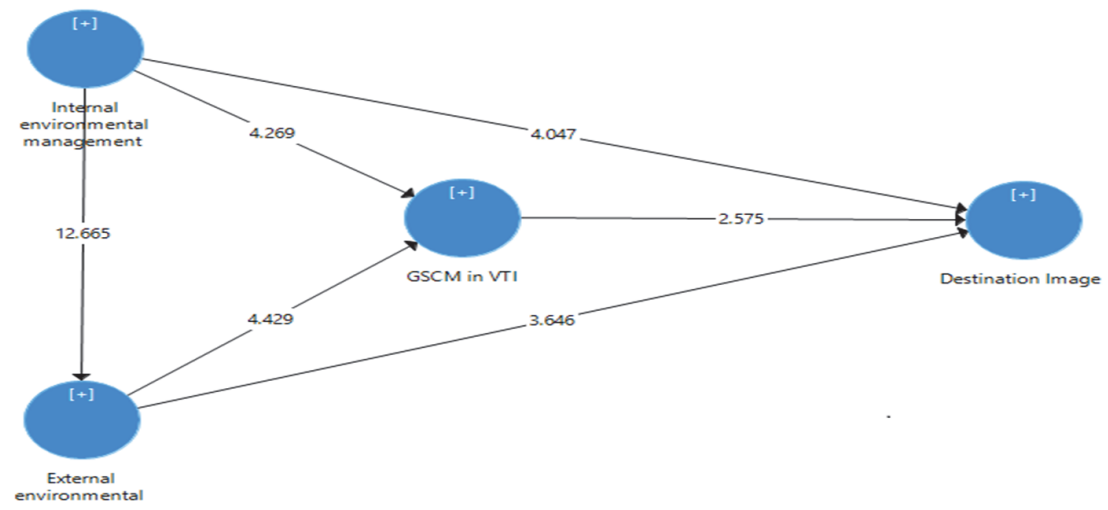

Fig. 2. Research results

\section{Conclusion}

This study has proposed an empirical investigation to study the Green Supply Chain Management Practices and their effect on the destination image as an evidence for development of Vietnam Tourism Industry. While the existing models focused on GSCM only confirm the factors influencing on GSCM practice (Zhu et al., 2008; Chen et al., 2011; Diabat \& Govindan, 2011), there is a dearth of studies that attempt to examine the links among internal, external environment and GSCM especially in tourism industry. Also, in the research of green tourism, there are limited studies on the effect of GSCM on destination image. Applying PLS-SEM method, this study has contributed to the academic knowledge by examining tourism theory in the context of Vietnam. This study has also improved previous research model in tourism marketing (Zhang, 2007; Wang, 2012; Yang, 2013) by adding the important factor of destination image. Our model has given a more extended and integrated vision of the effects of GSCM on destination image and proposed and tested in all phases of tourism managers decision-making. On 
the other hand, by testing the relationship of GSCM with two independent factors: Internal and external environment, the result shows the need for applying the interactive marketing concept in promoting Vietnam tourism industry. The findings of this study are important since Vietnam has been gaining higher popularity as an appealing tourism destination but there are still limited researches on Vietnam tourism. Consumers who are using tourism services may be interested in companies that offer a cleaner and healthier overnight experience, while the growth in boutique eco-tourism suggests a growing clientele for such services. In tourism industry, organizations must take responsibility for ensuring the sustainability of all the inputs that go into their products. According to the results, the willingness of VTI to participate in GSCM initiatives heavily rested on two influential factors: internal environment management and external environment (with two sub-factor buyer and supplier). Also, environmental regulation in the initiatives influenced the participation of VTI that make the better destination image. Companies, suppliers, customers as well as governments who want to improve their environmental performance throughout the supply chain can obtain implications from this study. First, our results consistent with our expectations in hypotheses developed and literatures, the tourism companies have cooperated with suppliers and customers in practicing the green supply chain management or the tour operators have been under pressured by supplier and customer, these will be more willingness to engage in GSCMP and also make better destination image. This implies managers who intend to improve the competitiveness should enhance environmental procurement and support to their suppliers and customers. From the limitations of this paper, we suggest directions for future research. The sample used in this study was extracted from Hanoi, Vietnam, so it may not represent all tourism companies in VTI comprehensively. Moreover, a relatively low response rate and a small number of samples might have created grounds for bias. In addition, the fact that each questionnaire was answered by only managers can be seen as the third limitation because a single respondent was likely to cause common method variance.

\section{Acknowledgement}

This research is funded by the Korea Foundation for Advanced Studies (KFAS) and the Asia Research Center, Vietnam National University, Hanoi (ARC-VNU) under project number CA.18.2A.

\section{References}

An, H. K., Amano, T., Utsumi, H., \& Matsui, S. (2008). A framework for green supply chain management complying with RoHS directive. Queen's University Belfast.

Beamon, B. M. (1999). Measuring supply chain performance. International journal of operations \& production management, 19(3), 275-292.

Berezan, O., Raab, C., Yoo, M., \& Love, C. (2013). Sustainable hotel practices and nationality: The impact on guest satisfaction and guest intention to return. International Journal of Hospitality Management, 34, $227-$ 233.

Bowen, F., Cousins, P., Lamming, R., \& Faruk, A. (2006). Horses for courses: explaining the gap between the theory and practice of green supply. In Greening the supply chain (pp. 151-172). Springer, London.

Cagno, E., Guido, M. J. L., Perotti, S., \& Zorzini, M. (2011). The impact of green supply chain practices on company performance: the case of 3PLs.

Carter, C. R., \& Rogers, D. S. (2008). A framework of sustainable supply chain management: moving toward new theory. International Journal of Physical Distribution \& Logistics Management, 38(5), 360-387.

Chien, M. K., \& Shih, L. H. (2007). An empirical study of the implementation of green supply chain management practices in the electrical and electronic industry and their relation to organizational performances. International Journal of Environmental Science and Technology, 4(3), 383-394.

Dam, D.X (2017). Factors affecting tourist destination choice: A survey of international travelers to Hanoi, Vietnam. Journal of Economics and Development, 19(1), 88-102.

Dunn, D. (2005). Venice observed: The traveller, the tourist, the post-tourist and British television. Discourse, communication and tourism, 98-120.

Jang, Y. J., Kim, W. G., \& Lee, H. Y. (2015). Coffee shop consumers' emotional attachment and loyalty to green stores: The moderating role of green consciousness. International Journal of Hospitality Management, 44, 146-156. 
Lai, W. H., \& Vinh, N. Q. (2012). A study of analyzing the selection of promotion activities and destination attributes in tourism industry in Vietnam from the perspective of tourism industrial service network (TISN). International Journal of Social and Human Sciences, 6, 330-336.

Lai, W. H., \& Vinh, N. Q. (2013). Online promotion and its influence on destination awareness and loyalty in the tourism industry. Advances in Management and Applied Economics, 3(3), 15.

Lin, R. J. (2013). Using fuzzy DEMATEL to evaluate the green supply chain management practices. Journal of Cleaner Production, 40, 32-39.

Ling, R. (2015). A review of Tourism Supply Chain based on the Perspective of sustainable development. $J$ Econ Sustain Develop, 6, 128-132.

Nguyen T.T. (2010). The effects of tourism supply chain on domestic tourists' decision for resuming visits to Nhatrang city. Journal of technology and science, Danang university, Vietnam.

Phan, T. T. A. (2019). Does organizational innovation always lead to better performance? A study of firms in Vietnam. Journal of Economics and Development, 21(1), 72-84.

Sarkis, J. (2012). A boundaries and flows perspective of green supply chain management. Supply Chain Management: An International journal, 17(2), 202-216.

Ho, J. C., Shalishali, M. K., Tseng, T., \& Ang, D. S. (2009). Opportunities in green supply chain management. The Coastal Business Journal, 8(1), 18-31.

Sigala, M. (2008). A supply chain management approach for investigating the role of tour operators on sustainable tourism: the case of TUI. Journal of Cleaner Production, 16(15), 1589-1599.

Sundarakani, B., de Souza, R., Goh, M., Van Over, D., Manikandan, S., \& Koh, S. L. (2010). A sustainable green supply chain for globally integrated networks. In Enterprise networks and logistics for agile manufacturing (pp. 191-206). Springer, London.

Tseng, M. L. (2010). Using linguistic preferences and grey relational analysis to evaluate the environmental knowledge management capacity. Expert systems with applications, 37(1), 70-81.

U.S. Travel Association, (2009). American travelers more familiar with 'green travel' but unwilling to pay more to support it.

Vachon, S., \& Klassen, R. D. (2008). Environmental management and manufacturing performance: The role of collaboration in the supply chain. International journal of production economics, 111(2), 299-315.

Vachon, S., \& Klassen, R. D. (2006). Extending green practices across the supply chain: the impact of upstream and downstream integration. International Journal of Operations \& Production Management, 26(7), 795821.

Vinh, N.Q., Anh, N.V., \& Trang, T.V. (2015). Willingness to apply the green supply chain management in hotel industry. Global Journal of Advance Research, 2(1), 321-334.

Wang, X. (2012). Tourism supply chain flexibility research - oriented tourism service trade. Journal of Economics and Sustainable Development, 6(22).

Xu, D. Gursoy, D. (2015). Influence of sustainable hospitality supply chain management on customers' attitudes and behaviors. International Journal of Hospitality Management, 49, 105-116.

$\mathrm{Xu}, \mathrm{X} .$, \& Gursoy, D. (2015). A conceptual framework of sustainable hospitality supply chain management. Journal of Hospitality Marketing Management, 24, 229-259.

Yang, L. (2013) Tourism cooperation of supply chain coordination research, from the perspectives of product differentiation. Foreign economic and trade university press

Zhang, S. (2007). The application of the green supply chain management in ecotourism product development research. Journal of Productivity Research, 2, 132-134.

Zhang, X., Song, H., \& Huang, G. Q. (2009). Tourism supply chain management: A new research agenda. Tourism management, 30(3), 345-358.

Zhu, Q., Sarkis, J., \& Lai, K. H. (2008). Confirmation of a measurement model for green supply chain management practices implementation. International Journal of Production Economics, 111(2), 261-273.

Zhu, Q., \& Sarkis, J. (2006). An inter-sectoral comparison of green supply chain management in China: drivers and practices. Journal of Cleaner Production, 14(5), 472-486.

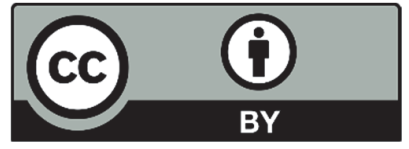

(C) 2020 by the authors; licensee Growing Science, Canada. This is an open access article distributed under the terms and conditions of the Creative Commons Attribution (CC-BY) license (http://creativecommons.org/licenses/by/4.0/). 